\title{
Chemical analysis and short-term toxicological evaluation of Beniseed (Sesanum indicum) oil in albino rats
}

\author{
Ibironke A. Ajayi, Rofiat Kilani and Aghanu N. Vivian \\ Industrial unit, Chemistry Department, Faculty of Science, University of Ibadan, Ibadan, Nigeria
}

\begin{abstract}
The proximate and physicochemical analyses of Beniseed (Sesamum indicum) were carried out. The seed contains $4.12 \%$ moisture, $31.59 \%$ crude protein, $32.60 \%$ crude fat, $10.85 \%$ crude fibre, $5.27 \%$ ash and $26.41 \%$ carbohydrate. The physicochemical characteristics of the golden yellow oil are as follows: acid value $(4.49 \pm 0.10 \mathrm{mgKOH} / \mathrm{g})$, iodine value $(85.75 \pm 0.92 \mathrm{~g} / 100 \mathrm{~g}$ oil $)$, saponification value $(71.95 \pm 0.20 \mathrm{mgKOH} / \mathrm{g})$, peroxide value $(2.65 \pm 0.21)$ and refractive index $(1.40 \pm 0.01)$. The seed was also found to be good sources of minerals; calcium $(9190 \pm 55.68 \mathrm{mg} / \mathrm{kg})$, potassium $(4713.33 \pm 35.12 \mathrm{mg} / \mathrm{kg})$ and magnesium $(3508.33 \pm$ $2.89 \mathrm{mg} / \mathrm{kg}$ ). $5 \%$ of Beniseed oil was incorporated into the formulation of albino rat feed. This feed served as the test diet while 5\% of groundnut oil replaced Beniseed oil in the control diet. There were increments in the proximate composition of the compounded feed. The experiment which lasted for eight weeks showed that the albino rats appeared to suffer no toxicological effect and weekly monitoring showed good physical appearance. The rats in the test group consumed more feed and recorded significant body weight gain when compared to their counter parts in the control group. Blood indices were analyzed for in the test and control rats and the results obtained revealed no adverse effect. There was no significant difference between the histopathology of the rat tissues harvested from the two groups. Beniseed appeared to be promising as a replacement for the more conventional edible oils already employed in cooking and other industrial applications.
\end{abstract}

Key words: Beniseed, nutritional composition, physicochemical characteristics, albino rats, diet.

\section{Introduction}

Plant biodiversity represents the primary source for food, feed, shelter, medicines and many other products and means that make life on earth possible and enjoyable (UNEP, 1995). The number of plant species used by humans around the world is only one third of the number of species which generations of diverse cultures around the world have drawn upon to develop crops that would meet specific needs. These underutilized crops (referred to also by other terms such as minor, neglected, underexploited, underdeveloped crops) have been included in world-wide plans of action and are being often presented as 'new crops' (Vietmeyer, 1990) for the fact that commercial companies and researchers are only recently working on them. In reality, local populations over generations have used these species. Yet the loss of local knowledge and thus the increasing ignorance of new generations on the traditional uses of these crops also contribute to portray such a misleading image. A crop can be completely new to an area simply because it has been introduced there recently from a distant country as in the case of the kiwi fruit which is unknown outside China or New Zealand till recently (Ferguson, 1999). Seed oils are important sources of nutritional oils and they are of industrial and pharmaceutical importance. The characteristics of oils from different sources depend mainly on their compositions and no oil from a single source can be suitable for all purposes. The study of these constituents is important for their effective uses.

Beniseed, grown mostly in tropical countries, can be used wholly or can be crushed for oil and meal. In the United States, the whole seed is used primarily as a topping for bakery products, principally in competition with poppy seed, and as a filling in pastries and candy (Maliki, 1999). Some low-grade sesame seed is also used for birdseed. The traditional use of Beniseed (also known as Ekuku in Yoruba and Igorigo in Igbira) dates back to about 4000 years ago in Babylon and Assyria where it was used to produce sesame cake, wine, brandy etc (Adebowale et al., 2007). There is need to carry out more research on both the defatted seed and the oil. This study focuses on the nutritional and chemical composition of Beniseed and its oil in continuance of the search for the replacement of conventional edible oils with lesser known edible seed oils.

\section{Sample collection and preparation}

\section{Materials And Methods}

Beniseed used for this study was purchased from a local market, in Ibadan, Oyo State, Nigeria in May, 2012. The seeds were sorted, cleaned, dehulled and then fairly ground using mortar and pestle in preparation for seed oil extraction. 


\section{Seed oil extraction}

Beniseed oil was extracted using hexane as a solvent in a cold extraction method. The solvent was distilled off the mixture after which the oil was recovered and kept for further analysis and feed compoundment.

\section{Proximate analysis of Beniseed}

Moisture, crude protein, crude fat, total carbohydrates and crude fibre were determined in Beniseed as outlined in AOAC (AOAC, 1990).

\section{Mineral composition of Beniseed}

Beniseed was digested by wet digestion method using a mixture of nitric, sulphuric and hydrochloric acids. Nutritionally significant metals were determined by atomic absorption spectrophotometer (Perkin-Elmer, Model 2380, USA) as outlined by AOAC (1996).

\section{Physicochemical characteristics of Beniseed oil}

Physicochemical properties of Beniseed and groundnut oils (acid value, iodine value, saponification value, peroxide value, free fatty acid (as oleic acid) and refractive index at $29^{\circ} \mathrm{C}$ using Abbe refractometer) were determined as outlined by AOAC (1996).

\section{Experimental animals}

Six weeks old albino rats $(\mathrm{n}=14)$, weighing between $50-80 \mathrm{~g}$ were used for this experiment. They were obtained from the Animal house of the Veterinary Department, University of Ibadan, Nigeria. The animals were divided into 2 groups (A and B) of seven rats per group and were fed for a period of 8 weeks before sacrifice. They were allowed to acclimatize for two weeks before the commencement of the experiment. The amount of feed consumed was recorded daily. Weekly weights of the rat were also recorded through out the 8 weeks feeding period. The animals were handled according to the guidelines of the Ethical Committee on the Use and Care of Experimental Animals Unit of the Department of Veterinary Medicine, University of Ibadan, Nigeria.

\section{Feed compoundment}

Feed was formulated to meet the entire nutrient requirement for young rats. The feed was prepared according to the method employed by Toyomizu et al. (2003) with slight modification. Basic ingredients used in compounding the experimental rat feed were: maize $(40 \%)$, soy bean $(18.21 \%)$, groundnut cake $(9.45 \%)$, Beniseed oil $(5 \%)$, bone $(3.30 \%)$, salt $(0.79 \%)$, palm kernel $(0.7 \%)$, wheat $(0.7 \%)$, corn bran $(0.7 \%)$ and limestone (2.26\%). The control feed had 5\% of groundnut oil as a total replacement for the 5\% of Beniseed oil in the experimental feed. These ingredients were thoroughly mixed with the aid of a mixing machine, pelletized and dried.

\section{Blood sample and tissue collection}

Blood sample was collected via ocular puncture into sample bottles containing EDTA and haematological studies were carried out. The animals were sacrificed through cervical dislocation and dissected to expose the internal organs. The tissues collected were kidney, heart, spleen, lungs, small intestine, brain and liver. These organs were weighed immediately after collection and cut into two; one-part was preserved in $10 \%$ formalin for pathological studies. Photomicrograph slide of the organs were prepared and observed (Ajayi et al., 2007).

\section{Haematology analysis}

White blood cell (WBC) and red blood cell (RBC) were determined using Neubaurer haemocytometer. Packed cell volume (PCV) was determined by microhaematocrit centrifuge. Mean corpuscular haemoglobin $(\mathrm{MCH})$ and Mean corpuscular haemoglobin concentration (MCHC) were determined according to the method of Jain (1986).

\section{Statistical Analysis}

Means were analyzed using a one-way analysis of variance (ANOVA) and complemented with Student's t-test. Differences with values of $\mathrm{P}<0.05$ were considered statistically significant (Mahajan, 1997).

\section{Results And Discussion}

The proximate composition of Beniseed together with those of the control and test feeds compounded with groundnut and Beniseed oils are shown on Table 1. The moisture content of Beniseed, control and test feeds were $4.12 \pm 0.12 \%, 13.11 \pm 0.02 \%$ and $13.33 \pm 0.04 \%$ respectively. This will result in low microbial activities in the seed which is an indication of good shelf life. The protein content of Beniseed $(31.59 \pm 0.13 \%)$ 
is close to those of soybean, cowpea, peanut, melon, pumpkin and gourd seeds $(23.1-33.0 \%)$ as reported by Olaofe et al. (1994). The control and test feeds also contained $21.74 \pm 0.13 \%$ and $21.52 \pm 0.13 \%$ crude protein respectively. The crude fat content of Beniseed $(32.60 \pm 0.15 \%)$ is moderately high. It is closely related to $36.7 \%$ that has been reported for cashew nut by Aremu et al. (2006). Fat is important in diet because it promotes the absorption of fat soluble vitamins (Bogert et al., 1995) and is a high energy nutrient. Therefore, Beniseed could serve as a good source of dietary fats and oil because of its high oil content. The crude fibre content of Beniseed $(10.85 \pm 0.07 \%)$ is an indication that it can contribute to the roughage of diet. Crude fibre helps to maintain intestinal distention for a normal peristaltic movement of the gastrointestinal tract. Diets low in fibre is undesirable as it could cause constipation and also be associated with diseases of the colon (Okon, 1983). Diet (feeds) having an appreciable amount of fibre is therefore desirable. Ash content of Beniseed (5.27 $\pm 0.16 \%$ ) is an account of the inorganic materials present in the seed and also an index for the quality of feeding materials used for poultry and cattle feeding. The carbohydrate content of Beniseed ( $26.41 \pm 0.14 \%)$, control and test feeds $(51.76 \pm 0.13 \mathrm{~s} \%$ and $52.41 \pm 0.11 \%$ respectively) are comparable to values for legumes. Beniseed seems to be a rich source of necessary nutrients and energy; it might be capable of supplying the daily nutritional and energy requirements of the body.

The physicochemical properties of Beniseed oil used in this study are shown on Table 2. The peroxide value of Beniseed oil was $2.65 \pm 0.21 \mathrm{meq} / \mathrm{kg}$. This is an indication that the oil was not rancid and is thus stable (Ajayi et al., 2002). This peroxide value compares well with some other cultivars of Sesamum indicum (Alyemeni et al., 2011). The iodine value of $85.75 \pm 0.92 \mathrm{~g} / 100 \mathrm{~g}$ that was obtained for Beniseed oil places it as a non drying oil. This iodine value is lower than what Ali et al., (2008) reported for varieties of Momordica charantia seed oils. It is higher than the value reported by Onyeike and Acheru (2002) for groundnut oil. The saponification value of Beniseed oil was $71.95 \pm 0.20 \mathrm{mgKOH} / \mathrm{g}$; it is lower when compared to the value reported for Beniseed oil (189.54 \pm 0.3$)$ by Njoku et al. (2010). The saponification values of some vegetable oils ranges between $188-255 \mathrm{mgKOH} / \mathrm{g}$ (Aremu et al., 2006) thus making them useful in soap making. Beniseed oil might not be suitable for soap making. The acid value of Beniseed oil $(4.49 \pm 0.10 \mathrm{mgKOH} / \mathrm{g})$ compares well with that of Jatropha curcas (Adebowale and Adedire, 2006). The specific gravity of Beniseed oil was found to be $0.91 \pm 0.01$.

Beniseed is rich in calcium $(9190.00 \pm 55.68 \mathrm{mg} / \mathrm{kg})$, potassium $(4713.33 \pm 35.12 \mathrm{mg} / \mathrm{kg})$ and magnesium $(3508.33 \pm 2.89 \mathrm{mg} / \mathrm{kg})$. It also contains sodium and iron in lower concentration $(311.33 \pm$ $13.01 \mathrm{mg} / \mathrm{kg}$ and $223.33 \pm 3.51 \mathrm{mg} / \mathrm{kg}$ respectively). Potassium is an essential nutrient and has an important role is the synthesis of amino acids and proteins while calcium is needed for bone formation and it plays a vital role in photosynthesis (Aremu et al., 2006).

Tables 4 and 5 show the average body weight changes and feed consumed per week of rats in both control and experimental groups. Positive weight changes were recorded for the rats in each group within the period of this study. In group A (the control group), the weight increased from $63.41 \pm 12.57 \mathrm{~g}$ to $201.63 \pm$ $18.34 \mathrm{~g}$ while in group B (the experimental group), it increased from $74.44 \pm 6.30 \mathrm{~g}$ to $219.69 \pm 29.90 \mathrm{~g}$. The observed increase in body weight of rats is an indication that $5 \%$ inclusion of both Beniseed and groundnut oils in the rat feed was nutritious and supported the rats' growth. For the feed intake, there was a positive increase in each group, the average feed intake per week increased from $123.97 \pm 97 \mathrm{~g}$ to $188.81 \pm 18.37 \mathrm{~g}$ and from $130.07 \mathrm{~g}$ $\pm 11.40 \mathrm{~g}$ to $179.41 \pm 7.12 \mathrm{~g}$ for the control and experimental groups respectively.

Organ weight of experimental and control rats harvested after eight weeks of the study are shown in Table 6. The following organs were weighed; liver, kidney, brain, intestine, spleen, heart and lungs. There were no significant differences in organs weights between the two groups.

Haematological parameters provide vital information regarding the status of bone marrow activity and intravascular effect such as haemolysis. Table 7 shows the result of haematological analysis of blood of rats fed with 5\% inclusion of Beniseed oil. The parameters in both groups are comparable but with slight differences in white blood cell and platelets showing that Beniseed oil had no adverse effect on the blood of experimental rats.

One of the lungs of the test rats had widespread proliferative thickening of the alveolar interstitium (Fig. 1) and there was a mild single-cell necrosis, widespread slight Kupffer cell hyperplasia and moderate dissociation of the hepatic cords which may be due to autolysis of the tissue in a liver of the rats fed with $5 \%$ of Beniseed oil (Fig. 2). Sections of flatworms (right aspect of photomicrograph) were noticed in the intestinal lumen of a test rat as well as numerous eosinophils in the lamina propria of the villi. Numerous goblet cells were also seen in the mucosa (Fig. 3). There was no visible lesion in the heart of all the test rats.

\section{Conclusion}

The moderately high oil yield of Beniseed is promising; it suggests that it could be possible to obtain commercial quantities of Beniseed oil for industrial, pharmaceutical and nutritional purposes. The oil exhibited good physicochemical properties that could be useful for various applications. It is a non drying oil; it might 
therefore be suitable for certain industrial formulations and dietary products. Beniseed has also been found to be a good source of crude protein and mineral elements. Some organs of the test rats showed some lesions but they still compared well with those of the control rats. The heart of the test rats showed no lesions. Result of blood haematology and tissue pathology from both groups registered no serious variations. Beniseed oil might find usefulness as edible oil in replacement of known vegetable oils.

\section{Acknowlegdement}

The Department of Chemistry in Faculty of Science and Veterinary Pathology in Faculty of Veterinary Medicine, both of University of Ibadan, Ibadan, Nigeria is hereby acknowledged for making their facilities available.

\section{References}

[1]. Adebowale, A.A., Sanni, S.A. and Odusami, B.O. (2007). Proximate and sensory propertiesof cassava-cowpea snacks. Proceedings of $31^{\text {st }}$ Annual Conference and General Meeting of Nigerian Institute of Food Science and Technology.

[2]. Adebowale, K.O. and Adedire, C.O. (2006). Chemical composition and insecticidal properties of the underutilized Jatropha curcas seed oil. African Journal of Biotechnology 5 (10): 901-906.

[3]. Ajayi, I.A., Dawodu, F.A., Adebowale, K.O. and Oderinde, R.A. (2002). Chemical composition of Pentaclethra macrophylla seeds and seed oil grown in Nigeria. La Rivista Italiana Sostanze Grasse. 79: 183-185.

[4]. Ajayi, I.A., Oderinde, R.A., Ogunkoya, B.O., Egunyomi, A. and Taiwo, V.O. (2007). Chemical analysis and preliminary toxicological evaluation of Garcinia mangostana seeds and seeds oil. Food Chemistry. 101: 999-1004.

[5]. Ali, M.A., Sayeed, M.A., Reza, M.S., Yeasmin, M.S. and Khan, A.M. (2008). Characteristics of seed oils and nutritional compositions of seeds from different varieties of Momordica charantia Linn. Cultivated in Bangladesh. Czech Journal of Food Science. 26: 275-283

[6]. Alyemeni, M.N., Basahy, A.Y. and Sher, H. (2011). Physico-chemical analysis and mineral composition of some sesame seeds (Sesamum indicum L.) grown in the Gizan area of Saudi Arabia. Journal of Medicinal Plants Research 5 (2): 270-274.

[7]. Aremu, M.O., Olanisakin, A., Bako, D.A. and Madu, P.C., (2006). Compositional studies and physiochemical characteristics of cashew nut (Anarcadium occidentale) flour. Pakistan Journal of Nutrition. 5 (4): 328-333.

[8]. AOAC (1990). Official Method of Analysis. 15th Edition Association of Official Analytical Chemists. Washington DC. Pp. $220-224$

[9]. AOAC, (1996). Sampling and analysis of commercial fat and triglycerides. Official Method of Analysis of the American Chemist Society. Pp. 801-855.

[10]. Bogert, J.L., Bags, G.M. and Galloeay, D.H., (1994). Nutrition and Physical Fitness. International Journal Fsood Science and Nutrition. 45: 223-230.

[11]. Ferguson, A.R., (1999). New temperate fruits: Actinidia chinensis and Actinidia deliciosa. Perspective on New Crops and New Uses (J. Janick Ed.). Pp. 342-347.

[12]. Jain, N.C. (1986). Schalms Veterinary Haematology $4^{\text {th }}$ Edition. Lea and Febiger. Philadephia. USA.

[13]. Maliki, K. (1999). Investigation of Storage Stability of "Kokoro". Nigerian Food Journal. 22: 58

[14]. Okon, B.D., (1983). Studies on the chemical composition and nutritive value of the fruit of African star apple. M. Sc thesis, University of Calabar, Pp. 67.

[15]. Olaofe, O., Adeyemi, F.O. and Adediran G.O., (1994). Amino acid and mineral composition and functional properties of some oil seeds. Journal of Agricultural and Food Chemistry. 42: 878-884.

[16]. Onyeike, E.N. and Acheru, G.N. (2002). Chemical composition of selected Nigerian oil seeds and physicochemical properties of oil extracts. Food Chemistry. 77: 432-437.

[17]. Toyomizu, M., Nakai, Y., Nakatsu, T. and Akiba, Y. (2003). Inhibitory effect of dietary anacardic acid supplementation on cereal lesion formation following chicken coccidial infection. Animal Science Journal. 74: 105-109.

[18]. UNEP (1995). Global Biodiversity Assessment. United Nations Environment Programme University Press, Cambridge, UK

[19]. Vietmeyer, N. (1990). The New Crops Era. Pp. xviii-xxii in Advances in New crops. Proceedings of the First National Symposium on New Crops: Research, Development, Economics.

Table 1: Result of proximate composition of Beniseed and compounded feeds

\begin{tabular}{lrrr}
\hline Parameter (\%) & Beniseed & \multicolumn{1}{c}{ Group A } & \multicolumn{1}{c}{ Group B } \\
\hline Moisture content & $4.12 \pm 0.12$ & $13.11 \pm 0.02$ & $13.33 \pm 0.04$ \\
Crude protein & $31.59 \pm 0.13$ & $21.74 \pm 0.13$ & $21.52 \pm 0.13$ \\
Crude fibre & $10.85 \pm 0.07$ & $8.77 \pm 0.03$ & $8.50 \pm 0.02$ \\
Crude fat & $32.60 \pm 0.15$ & $4.62 \pm 0.04$ & $3.44 \pm 0.04$ \\
Ash content & $5.27 \pm 0.16$ & $8.77 \pm 0.21$ & $9.29 \pm 0.06$ \\
Carbohydrate content & $26.41 \pm 0.14$ & $51.76 \pm 0.13$ & $52.41 \pm 0.11$ \\
\hline
\end{tabular}

Values are expressed as Mean \pm SD for 3 replicates

Table 2: Physicochemical characteristics of Beniseed oil

\begin{tabular}{lc}
\hline Parameter & Beniseed oil \\
\hline Iodine value (mg/100g) & $85.75 \pm 0.92$ \\
Peroxide value (mg/g oil) & $2.65 \pm 0.21$ \\
Saponification value (mgKOH/g) & $71.95 \pm 0.20$ \\
Acid value (mgKOH/g) & $4.49 \pm 0.10$ \\
Specific gravity & $0.91 \pm 0.01$ \\
Refractive index at RT & $1.40 \pm 0.01$ \\
Colour & Golden yellow \\
\hline
\end{tabular}


Values are expressed as Mean \pm SD for 3 replicates

Table 3: Result of metal composition of Beniseed

\begin{tabular}{lc}
\hline Metal & Concentration $(\mathbf{m g} / \mathbf{k g})$ \\
\hline Calcium & $9190.00 \pm 55.68$ \\
Magnesium & $3508.33 \pm 2.89$ \\
Potassium & $4713.33 \pm 35.12$ \\
Sodium & $311.33 \pm 13.01$ \\
Manganese & $11.00 \pm 0.00$ \\
Iron & $223.33 \pm 3.51$ \\
Copper & $6.11 \pm 0.20$ \\
Zinc & $43.80 \pm 0.12$ \\
\hline
\end{tabular}

Table 4: Average weight increase of rats (g)

\begin{tabular}{lcc}
\hline & Group A & Group B \\
\hline 0 & $63.41 \pm 12.57$ & $74.44 \pm 6.30$ \\
1 & $89.59 \pm 14.11$ & $100.63 \pm 7.85$ \\
2 & $111.11 \pm 16.82$ & $124.41 \pm 11.33$ \\
3 & $134.32 \pm 16.78$ & $145.33 \pm 18.09$ \\
4 & $157.63 \pm 20.98$ & $173.65 \pm 24.74$ \\
5 & $169.87 \pm 23.67$ & $193.42 \pm 28.39$ \\
6 & $191.03 \pm 23.56$ & $207.68 \pm 30.41$ \\
7 & $203.51 \pm 19.67$ & $223.72 \pm 34.69$ \\
8 & $201.63 \pm 18.34$ & $219.69 \pm 29.90$
\end{tabular}

Values are expressed as Mean \pm SD 3 replicates

Table 5: Average feed consumed by rats per week (g)

\begin{tabular}{lcc}
\hline Week & Group A & Group B \\
\hline 1 & $123.97 \pm 97$ & $130.07 \pm 11.40$ \\
2 & $167.86 \pm 21.26$ & $157.37 \pm 18.48$ \\
3 & $150.13 \pm 13.21$ & $174.04 \pm 8.55$ \\
4 & $166.90 \pm 15.92$ & $176.80 \pm 12.79$ \\
5 & $187.66 \pm 16.61$ & $164.53 \pm 14.60$ \\
6 & $194.03 \pm 15.44$ & $184.47 \pm 12.41$ \\
7 & $195.79 \pm 16.34$ & $183.11 \pm 6.84$ \\
8 & $188.81 \pm 18.37$ & $179.41 \pm 7.12$ \\
Total & $1375.15 \pm 25.09$ & $1349.80 \pm 8.14$ \\
\hline
\end{tabular}

Values are expressed as Mean \pm SD for 3 replicates

Table 6: Weight of tissues (g)

\begin{tabular}{lcc}
\hline Tissue & Group A & Group B \\
\hline Liver & $6.07 \pm 0.39$ & $7.16 \pm 0.47$ \\
Kidney & $1.44 \pm 0.19$ & $1.34 \pm 0.21$ \\
Brain & $1.59 \pm 0.11$ & $1.46 \pm 0.23$ \\
Intestine & $1.81 \pm 0.11$ & $2.06 \pm 0.47$ \\
Spleen & $0.67 \pm 0.11$ & $0.68 \pm 0.14$ \\
Heart & $0.66 \pm 0.05$ & $0.67 \pm 0.11$ \\
Lung & $1.64 \pm 0.19$ & $1.56 \pm 0.24$ \\
\hline
\end{tabular}

Values are expressed as Mean \pm SD

Table 7: Results of Haematological analysis

\begin{tabular}{lcc}
\hline Parameter & Group A & Group B \\
\hline PCV & $49.00 \pm 2.77$ & $51.40 \pm 1.82$ \\
$\mathrm{Hb}$ & $15.46 \pm 0.78$ & $15.66 \pm 1.22$ \\
$\mathrm{RBC}$ & $8.31 \pm 0.57$ & $8.60 \pm 0.48$ \\
$\mathrm{WBC}$ & $4471.43 \pm 1230.80$ & $6280.00 \pm 1172.92$ \\
MCV & $59.03 \pm 1.37$ & $59.83 \pm 2.02$ \\
MCHC $(\%)$ & $31.57 \pm 0.89$ & $30.47 \pm 2.21$ \\
MCH & $18.04 \pm 0.90$ & $18.24 \pm 1.59$ \\
Lymphocyte (\%) & $68.71 \pm 10.48$ & $63.20 \pm 17.88$ \\
Neutrophyl $(\%)$ & $27.43 \pm 8.98$ & $34.20 \pm 18.01$ \\
Eosinophyl (\%) & $1.71 \pm 1.38$ & $1.20 \pm 0.44$ \\
Monocyte $(\%)$ & $1.86 \pm 1.57$ & $1.20 \pm 0.44$ \\
\hline
\end{tabular}




\begin{tabular}{lcc}
\hline Absolute & & $3891.00 \pm 919 . .06$ \\
Lymphocyte & $2759.86 \pm 631.50$ & $2227.40 \pm 1342.42$ \\
Absolute & & \\
$\begin{array}{l}\text { Neutrophyl } \\
\text { Absolute }\end{array}$ & $1310.86 \pm 860.79$ & $57.10 \pm 19.56$ \\
$\begin{array}{l}\text { Eosinophyl } \\
\text { Absolute }\end{array}$ & $91.64 \pm 56.25$ & $75.10 \pm 29.22$ \\
$\begin{array}{l}\text { Monocyte } \\
\text { Platelets }\end{array}$ & $81.64 \pm 17.64$ & $102200 \pm 27626.07$ \\
\hline
\end{tabular}

Values are expressed as Mean \pm SD for 3 replicates

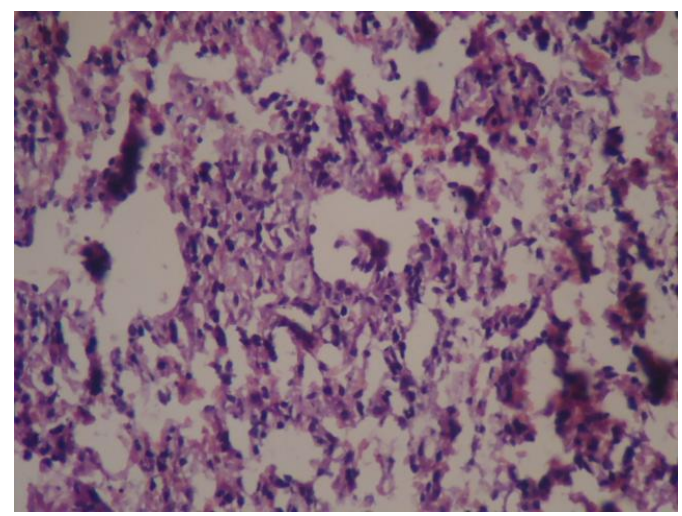

Fig. 1. Photomicrograph of lung of an experimental rat fed with 5\% of Beniseed oil in the diet showing widespread proliferative thickening of the alveolar interstitium (H\&E X 400).

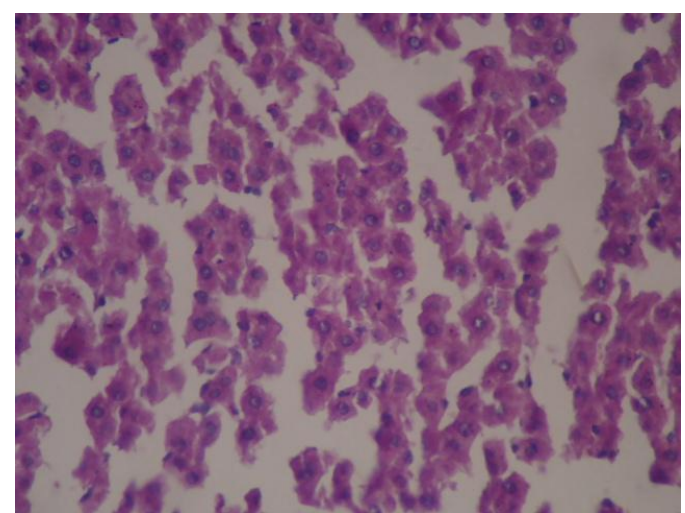

Fig. 2. Photomicrograph of an experimental rat liver fed with 5\% incorporation of Beniseed oil at a showing moderate dissociation of the hepatic cords which may be due to autolysis of the liver. (H\&E X 400)

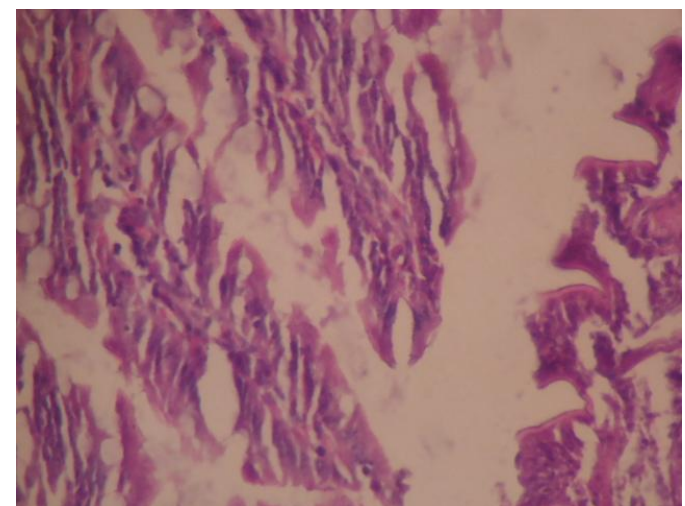

Fig. 3. Photomicrograph of a rat intestine in the experimental group (fed with 5\% Beniseed oil in the diets) showing sections of flatworms (right aspect of photomicrograph) in the intestinal lumen; there are numerous eosinophilis in the lamina propria of the villi and numerous goblet cells in the mucosa. (H\&E X 400) 